\title{
Leaf Serration in Seedlings of Heteroblastic Woody Species Enhance Plasticity and Performance in Gaps But Not in the Understory
}

\author{
Harshi K. Gamage ${ }^{1,2}$ \\ ${ }^{1}$ School of Biological Sciences, Victoria University of Wellington, P.O. Box 600, Wellington 6140, New Zealand \\ ${ }^{2}$ School of Biological Sciences, The University of Queensland, Brisbane QLD 4072, Australia \\ Correspondence should be addressed to Harshi K. Gamage, h.gamage@uq.edu.au
}

Received 12 October 2009; Revised 22 March 2010; Accepted 14 May 2010

Academic Editor: Mark S. Ashton

Copyright (c) 2010 Harshi K. Gamage. This is an open access article distributed under the Creative Commons Attribution License, which permits unrestricted use, distribution, and reproduction in any medium, provided the original work is properly cited.

Leaf heteroblasty refers to dramatic ontogenetic changes in leaf size and shape, in contrast to homoblasty that exhibits little change, between seedling and adult stages. This study examined whether the plasticity in leaf morphology of heteroblastic species would be an advantage for their survival and growth over homoblastic congeners to changes in light. Two congeneric pairs of homoblastic (Hoheria lyallii, Aristotelia serrata) and heteroblastic species (H. sexstylosa, A. fruticosa) were grown for 18 months in canopy gap and forest understory sites in a temperate rainforest in New Zealand. Heteroblastic species that initially had serrated leaves reduced leaf serration in the understory, but increased in the gaps. Heteroblastic species also produced thicker leaves and had higher stomatal pore area (density $\times$ aperture length), maximum photosynthetic rate, survival, and greater biomass allocation to shoots than homoblastic relatives in the gaps. Findings indicate that increased leaf serration in heteroblastic species is an advantage over homoblastic congeners in high light.

\section{Introduction}

As plants develop from seedlings to reproductive individuals they undergo many biochemical, morphological, and anatomical changes [1]. During this maturation process, plants can exhibit two or more ontogenetically different morphological types of leaves (heteroblasty). In contrast, other plants exhibit relatively little change in leaf morphology, ontogenetically (homoblasty) [2-5]. The variation of leaf morphology of heteroblastic plants may arise due to different proximate mechanisms, including programmed ontogenetic changes [3], phenotypic plasticity [6,7], or development instability in response to apparently random environmental heterogeneity [8]. However, evolutionary explanations for the heteroblastic syndrome remain unclear and include responses to herbivory $[9,10]$, climatic changes $[11,12]$, and changes in light environment $[3,6,9,13]$ and plant physiology $[14,15]$, or due to programmed ontogenetic changes [3].
Few studies have experimentally investigated the functional consequences of variation in leaf size and shape $[4,16]$. For example, the variation in leaf size and shape along the axis of an individual plant (heterophylly) is an effect of environmental factors in some plants while others reflect an inevitable effect to environmental factors that have neutral or negative effects on fitness [16]. An ontogenetic study of leaf anatomy and morphology of heteroblastic species Pseudopanax crassifolius showed that seedling leaves with entire or serrulate margins are an adaptation to low light [7]. Similar findings have been found for tropical vines (Monstera spp., Ipomoea spp.) where juveniles with entire leaves grow in the forest understory while the lobed adult leaves are an adaptation to high light in the overstory [6]. In Australia, low light environment delayed the shift in heteroblastic leaf formation in Acacia implexa [17] while juvenile Eucalyptus globulus posses leaf structural features that are similar to their sun-adapted adult plants [13]. These studies show that the differences in light environment trigger the heteroblastic leaf 
morphology, but their functional adaptation to high or low light is species specific.

Despite some understanding of leaf responses of heteroblastic plants to light, there are no studies that have investigated the functional consequences of heteroblastic variation in leaf shapes. In New Zealand, heteroblastic species are found in both understory and open sites in lowland, montane, and alpine forests. It has been suggested that the prevalence of heteroblastic syndrome in this flora is due to consistent selection pressures such as moa (ratti bird) browsing $[9,10]$ and climatic changes $[11,12]$. Here, I tested the hypothesis that consistent ontogenetic differences in light environment may select for heteroblasty. If variation in leaf morphology is an adaptation to changing light environment, the foliar responses of heteroblastic plants at seedling stage should optimize their survival and growth in low light in the forest understory. Therefore, I asked: "do heteroblastic seedlings gain any advantage over homoblastic congeners in low light?" Seedlings of two heteroblastic/homoblastic species pairs were grown in canopy gaps and forest understory sites to examine their growth, leaf anatomical, and physiological responses.

\section{Methods and Materials}

2.1. Study Site and Species. This study was conducted at Karori Wildlife Sanctuary, an ecological restoration site located in Wellington, New Zealand. The sanctuary is 249 ha in size and has a maximum elevation of $356 \mathrm{~m}$ a.s.l. The area was once covered by podocarp-broadleaf forest. The original forest was lost during extensive fires in the $1840 \mathrm{~s}$ and today the majority of the area is covered in regenerating native forest species [18]. The mean annual rainfall is $1235 \mathrm{~mm}$ and the mean annual temperature is $12.8^{\circ} \mathrm{C}$ [19]. The selected two pairs of heteroblastic and homoblastic species are common, native New Zealand plants, in genera Hoheria (Malvaceae) and Aristotelia (Elaeocarpaceae). These species were selected due to their seedlings availability during the time of the study. Heteroblastic H. sexstylosa is a tree with greater branching. The juvenile leaves are lobed while adult leaves are serrately margined. The homoblastic $H$. lyallii is a tree and leaves have serrate margins. Heteroblastic A. fruticosa is a small shrub. The juvenile stage is much branched producing reddishbrown, deeply toothed leaves. The adult leaves are green with a serrate margin. Homoblastic A. serrata (wineberry) is a small tree and the leaves have serrate margins [20].

2.2. Experimental Design. Three canopy openings were chosen for the experiment, each positioned at a similar elevation ( $160 \mathrm{~m}$ a.s. 1.). Pre-existing recent tree fall gaps were used for full-sun environments and adjacent ( $50 \mathrm{~m}$ away) forest understory sites for shade environments. One-year-old seedlings of homoblastic and heteroblastic species of Hoheria and Aristotelia seedlings (both homoblastic and heteroblastic species) were purchased from a nursery where they had been grown under $60 \%$ light. Five pairs of Hoheria and Aristotelia seedlings were planted in each gap and understory sites. There were 120 seedlings used in the experiment $(2$ light environments $\times 3$ sites $\times 4$ species $\times 5$ seedlings per species/site). Each congeneric homoblastic and heteroblastic pair was planted in a random position with $30 \mathrm{~cm}$ between each plant in a homoblastic and heteroblastic pair. The minimum distance between two pairs was $45 \mathrm{~cm}$. After 18 months of growth in gap and understory sites, measurements of leaf morphology, physiology, anatomy, and growth were taken.

2.3. Microclimatic Measurements. Photosynthetic photon flux densities (PPFDs) and air temperatures were measured during summer (January 2002) for three sunny days using light and air temperature sensors connected to an LI-1000 data logger. Light and temperature sensors (LI-190 SA, Licor Inc., Lincoln, Nebraska, USA) were set to take readings of PPFD every $10 \mathrm{~s}$. Ten-minute means for all light and temperature treatments in each gap and forest understory were simultaneously recorded over a 12 -h period using a data logger. Light sensors were positioned horizontally $30 \mathrm{~cm}$ above the forest floor within the light treatments. Air temperature sensors were attached to the poles where light sensors were located. The averaged maximum PPFD and air temperature recorded in the center of gaps was $2027 \pm 112 \mu \mathrm{mol} \mathrm{m}^{-2} \mathrm{~s}^{-1}$ and $27.3 \pm 3.1^{\circ} \mathrm{C}$, respectively. In the understory, the averaged maximum PPFD was $109 \pm$ $12 \mu \mathrm{mol} \mathrm{m}^{-2} \mathrm{~s}^{-1}$ while air temperature was $15.6 \pm 1.6^{\circ} \mathrm{C}$.

2.4. Leaf Morphology. Leaf serration differences between gap and forest understory light environments were measured as the ratio of leaf margin to area. Leaf number was recorded at the beginning and end of the experiment. The leaf area was measured for all seedlings (leaves that were developed in gap and understory light environments were used) at the end of the experiment using the LI-320 leaf area meter (Licor Inc., Lincoln, Nebraska, USA). The mean leaf size per seedling was estimated by dividing the total leaf area by the number of leaves of the same seedling. Specific leaf area was calculated as the ratio of total leaf area per seedling and total leaf dry mass gained by that seedling.

\subsection{Leaf Physiology}

2.5.1. Light Response Curves. Prior to harvesting, light response curves of photosynthetic rates were conducted using an LI-6400 infrared gas analyzer (Licor Inc., Lincoln, Nebraska, USA) on nine randomly selected seedlings for each Hoheria and Aristotelia species. From each seedling a fully expanded, undamaged, newly formed mature leaf was selected for measurements. Leaf temperature was maintained $25 \pm 1^{\circ} \mathrm{C}$ and water vapor pressure deficit was $1.0-1.2 \mathrm{kPa}$ during the photosynthesis measurements. Reference $\mathrm{CO}_{2}$ and $\mathrm{H}_{2} \mathrm{O}$ were maintained at $370 \pm 1$ p.p.m. and $20 \pm 2$, respectively. Light response curves for full-sun leaves were measured at 15 PPFD levels starting from $2000 \mu \mathrm{mol} \mathrm{m}^{-2} \mathrm{~s}^{-1}$ and then decreasing PPFD, while light response curves for shade leaves were measured from 13 PPFD levels starting from $1200 \mu \mathrm{mol} \mathrm{m}^{-2} \mathrm{~s}^{-1}$ since photoinhibition was observed at higher light levels. All measurements were taken during summer (November-January). For seedlings with leaves 
smaller than the leaf cuvette, the leaf area was remeasured using the leaf area meter when plants were destructively sampled. Photosynthesis was recalculated for those seedlings. I used a nonrectangular hyperbola to fit carbon assimilation rates with light curves to estimate the maximum light saturated photosynthetic rate [21]. Maximum photosynthetic rate was calculated for both unit leaf area and unit leaf mass. Stomatal conductance was recorded at maximum photosynthetic rate.

2.6. Leaf Anatomy. The same seedling leaves that were used for the physiological measurements were subsequently fixed and used for leaf anatomical measurements $(9$ seedlings per species). To determine cell dimensions, $1 \times 0.5 \mathrm{~cm}$ cross sections were taken across the midrib and immediately fixed in 70\% FAA (formalin : acetic acid : alcohol $=5: 5: 90$ ). The strips were dehydrated in an ethyl alcohol series and then embedded in separate wax blocks [22]. Cross sections were cut from each strip at $10 \mu \mathrm{m}$ thickness with a rotary microtome and mounted on glass slides. Three slides from each strip were prepared. The tissue was then stained with safranin and fast green [23].

To determine stomata density and stoma aperture length, $1 \times 1 \mathrm{~cm}$ leaf sections were taken from the sample leaf adjacent to the section used to measure cross section. Each section was incubated in a $50^{\circ} \mathrm{C}$ oven in $5 \%$ sodium hydroxide to clear leaf pigments. Sections were stained with 1-2 drops of $0.5 \%$ aqueous toluidine blue solutions and were mounted on slides [24]. In each section, the number of stomata was counted in five different fields of view using an ocular grid. From each section, three closed stoma aperture lengths were measured in five different fields of view on the abaxial side of the leaf using an ocular micrometer. No stomata were found on the adaxial leaf surfaces. Stomatal aperture area (the product of mean stoma aperture length and stomatal density) was estimated to obtain a relative comparison of stomatal aperture area among the species [24].

2.7. Seedling Survival, Growth, and Biomass Allocation. The number of seedlings that survived in gap and understory sites was recorded at the end of the experiment. Seedling height (from root collar to the tip of the apical shoot) and branch number were measured at the beginning and after 18 months of growth in gaps and understory sites. Plants were harvested by digging soil from around the plant, after which soil was washed from the roots. It is likely that some fine roots were lost during this procedure. Seedlings were oven dried at $85^{\circ} \mathrm{C}$, and dry mass of leaves, shoots (main shoot and branches), and roots (tap root and fine roots) were recorded. Proportional biomass allocation to seedling parts was calculated as the ratio of dry mass of plant part and total dry mass of the same seedling.

2.8. Statistical Analysis. To test for differences between congeneric pairs of homoblastic and heteroblastic species, I performed General Linear Models for each foliar and growth trait using MINITAB Version 12. All data were log transformed prior to analysis to meet the assumption of
ANOVA with the exception of proportional biomass allocation ratios. Differences among sites, light (gap and understory), genera, species (homoblastic/heteroblastic) nested within genera, and all two-way interactions were tested. Proportional biomass allocation ratios were Arcsine-Square root transformed and significant differences were examined using Wilk's test in MANOVA. The traits that had significant interaction at $P<.05$ level for light $\times$ species nested within genera were further compared (homoblastic versus heteroblastic) using a two sample $t$-test for each genera within gap and forest understory treatments, separately.

A plasticity index (the ratio of the mean in sun and the mean in shade (sun/shade; [23])) was used to determine the effect of sun and shade light environment on foliar response. This index indicates both the magnitude and the direction of plasticity for homoblastic and heteroblastic species for each measured variable. Traits that had significant differences between homoblastic and heteroblastic species were used for the calculation of plasticity index.

\section{Results}

3.1. Leaf Morphology. Light environment had a significant effect on the measured foliar traits of all species (Table 1). In comparison to initial leaf shapes, there was an increase in leaf serration for heteroblastic species but a decrease for homoblastic relatives in the gaps. All species reduced leaf serration in the understory (Figure 1, Table 2). Heteroblastic species also produced more smaller leaves per seedling relative to homoblastic congeners in both light environments. Two sample $t$-tests showed that the specific leaf area was lower for heteroblastic A. fruticosa but greater for heteroblastic $H$. sexstylosa than their paired species in gap and understory sites (Figure 2).

3.2. Leaf Physiology. Nested analysis of variance showed that the maximum photosynthetic rate $\left(A_{\max }\right)$ and stomatal conductance had significant interactions between light and species nested within genera (Table 1). In the gaps, heteroblastic species had significantly $(P<.05)$ higher $A_{\max }$ per unit leaf area and stomatal conductance than homoblastic congeners but not in the understory sites (Table 2). However, $A_{\max }$ per unit leaf mass was significantly higher only for heteroblastic $H$. sexstylosa in the gaps (Table 2).

3.3. Leaf Anatomy. The dimensions of leaf anatomical layers (thickness of the leaf blade, cuticle, upper epidermis, lower epidermis, and stomatal pore area) all differed significantly between homoblastic and heteroblastic species in both gap and understory light environments (Table 1). Two sample $t$-tests analysis showed that heteroblastic $H$. sexstylosa had a thinner leaf blade, cuticle, and epidermis than the homoblastic pair, while heteroblastic $A$. fruticosa had thicker leaf anatomical layers than homoblastic $A$. serrata both in gap and understory sites. Both heteroblastic species had significantly more stomatal pore area (stomatal density $\times$ stomatal aperture length) than their homoblastic relatives both in gap and understory sites (Table 3 ). 
TABLE 1: Summary of significant differences of the nested analysis of variances for seedling growth, leaf morphological, physiological, and anatomical traits. Measures were taken from fifteen seedlings/species for growth and leaf morphology while nine seedlings/species were used for leaf physiology and anatomy from canopy gap and forest understory sites. Species was coded as either homoblasty or heteroblasty. Degree of significance: ${ }^{* * *} P<.001,{ }^{* *} P<.01,{ }^{*} P<.05$. There was no significant differences across sties.

\begin{tabular}{|c|c|c|c|c|c|}
\hline & Light & Genera & Species & Light $\times$ Genera & $\begin{array}{c}\text { Light } \times \text { Genera } \times \text { Species } \\
(\text { Genera })\end{array}$ \\
\hline \multicolumn{6}{|l|}{ Growth traits } \\
\hline Height increment & $* * *$ & $*$ & ns & ns & $* * *$ \\
\hline Number of branches & $* * *$ & $* * *$ & $* * *$ & $* *$ & $* * *$ \\
\hline Total dry mass & $* * *$ & $* * *$ & $* * *$ & $* * *$ & $* * *$ \\
\hline $\begin{array}{l}\text { Biomass allocation } \\
\text { (leaves, shoots, roots) }\end{array}$ & ns & $* * *$ & $* * *$ & ns & $*$ \\
\hline \multicolumn{6}{|l|}{ Leaf morphological traits } \\
\hline Number of leaves & $* * *$ & $* * *$ & $* * *$ & $*$ & $* * *$ \\
\hline Leaf size & $* *$ & $* * *$ & $* * *$ & ns & $* * *$ \\
\hline Specific leaf area & $* * *$ & ns & $* * *$ & ns & $* * *$ \\
\hline Total leaf area & $* * *$ & $*$ & $* * *$ & $* * *$ & $* * *$ \\
\hline \multicolumn{6}{|l|}{ Leaf physiological traits } \\
\hline $\begin{array}{l}\text { Max. photosynthetic rate } \\
\text { (unit leaf area) }\end{array}$ & $* * *$ & ns & $* * *$ & ns & $* * *$ \\
\hline $\begin{array}{l}\text { Max. photosynthetic rate } \\
\text { (unit leaf mass) }\end{array}$ & $* * *$ & ns & $* *$ & ns & $* *$ \\
\hline Stomatal conductance & $* * *$ & $*$ & $* * *$ & $*$ & $* * *$ \\
\hline \multicolumn{6}{|l|}{ Leaf anatomical traits } \\
\hline Leaf blade thickness & $* * *$ & $* * *$ & $* * *$ & $* * *$ & $* * *$ \\
\hline Cuticle thickness & $* * *$ & $* * *$ & $* * *$ & $* *$ & $* * *$ \\
\hline Upper epidermis thickness & $* * *$ & $* * *$ & $* * *$ & $* * *$ & $* * *$ \\
\hline Palisade mesophyll thickness & $* * *$ & $* * *$ & $* * *$ & ns & $* * *$ \\
\hline Lower epidermis thickness & $* * *$ & $* * *$ & $* * *$ & ns & $* * *$ \\
\hline Stomatal pore area (density $\times$ aperture length) & $* * *$ & $* * *$ & $* * *$ & $* * *$ & $* * *$ \\
\hline
\end{tabular}

TABLE 2: Seedling survival and maximum photosynthetic rate for homoblastic and heteroblastic (hetero) Hoheria and Aristotelia species in canopy gap and forest understory light environments. Data are mean values from nine seedlings with standard errors in parentheses. Means followed by different letters are significantly different at $P<.05$ level within a genus in gap and understory sites.

\begin{tabular}{lccccc}
\hline & $\begin{array}{c}\text { \% Seedling } \\
\text { Survival }\end{array}$ & $\begin{array}{c}\text { Ratio of leaf } \\
\text { margin to area } \\
\left(\mathrm{mm} / \mathrm{cm}^{2}\right)\end{array}$ & $\begin{array}{c}\text { Max. photosynthetic rate } \\
\left(\mu \mathrm{mol} \mathrm{CO} \mathrm{m}^{-2} \mathrm{~s}^{-1}\right)\end{array}$ & $\begin{array}{c}\text { Max. photosynthetic rate } \\
\left(\mu \mathrm{mol} \mathrm{CO}_{2} \mathrm{~g}^{-1} \mathrm{~s}^{-1}\right)\end{array}$ & $\begin{array}{c}\text { Stomatal conductance } \\
\left(\mathrm{mol} \mathrm{H}_{2} \mathrm{O} \mathrm{m}^{-2} \mathrm{~s}^{-1}\right)\end{array}$ \\
\hline $\begin{array}{l}\text { Forest understory } \\
\text { H. lyallii }\end{array}$ & 100 & 1.79 & $3.7(0.33)^{\mathrm{a}}$ & $0.098(0.073)^{\mathrm{a}}$ & $0.032(0.002)^{\mathrm{a}}$ \\
H. sexstylosa (hetero) & 100 & 0.52 & $3.5(0.32)^{\mathrm{a}}$ & $0.161(0.042)^{\mathrm{a}}$ & $0.028(0.002)^{\mathrm{a}}$ \\
A. serrata & 100 & 0.31 & $2.9(0.16)^{\mathrm{a}}$ & $0.102(0.011)^{\mathrm{a}}$ & $0.047(0.004)^{\mathrm{b}}$ \\
A. fruticosa (hetero) & 86 & 0.39 & $2.6(0.17)^{\mathrm{a}}$ & $0.054(0.006)^{\mathrm{b}}$ & $0.055(0.005)^{\mathrm{a}}$ \\
Canopygap & & & & $0.401(0.087)^{\mathrm{b}}$ & $0.266(0.028)^{\mathrm{b}}$ \\
H. lyallii & 86 & 0.74 & $13.8(0.36)^{\mathrm{b}}$ & $0.616(0.083)^{\mathrm{a}}$ & $0.391(0.049)^{\mathrm{a}}$ \\
H. sexstylosa (hetero) & 100 & 0.12 & $15.6(0.38)^{\mathrm{a}}$ & $0.505(0.043)^{\mathrm{a}}$ & $0.216(0.101)^{\mathrm{b}}$ \\
A. serrata & 33 & 0.02 & $11.9(0.32)^{\mathrm{b}}$ & $0.462(0.031)^{\mathrm{a}}$ & $0.506(0.034)^{\mathrm{a}}$ \\
A. fruticosa (hetero) & 100 & 0.29 & $16.7(0.74)^{\mathrm{a}}$ &
\end{tabular}


TABle 3: Means of the anatomical traits from nine homoblastic and heteroblastic (hetero) Hoheria and Aristotelia species in canopy gap and forest understory sites with standard errors in parenthesis. Species followed by the same letter are not different at $5 \%$ level of significance within a genus.

\begin{tabular}{|c|c|c|c|c|c|c|}
\hline & $\begin{array}{l}\text { Leaf blade } \\
\qquad(\mu \mathrm{m})\end{array}$ & $\begin{array}{l}\text { Cuticle } \\
(\mu \mathrm{m})\end{array}$ & $\begin{array}{l}\text { Upper epidermis } \\
\qquad(\mu \mathrm{m})\end{array}$ & $\begin{array}{l}\text { Palisade mesophyll } \\
\qquad(\mu \mathrm{m})\end{array}$ & $\begin{array}{l}\text { Lower epidermis } \\
\qquad(\mu \mathrm{m})\end{array}$ & $\begin{array}{c}\text { Stomatal pore area } \\
(\text { density } \times \text { aperture length }) \\
\left(\mu \mathrm{m} \mathrm{mm}^{-2}\right)\end{array}$ \\
\hline \multicolumn{7}{|l|}{ Forest understory } \\
\hline H. lyallii & $99.7(0.9)^{\mathrm{a}}$ & $0.87(0.02)^{\mathrm{a}}$ & $17.4(0.26)^{\mathrm{a}}$ & $26.8(0.23)^{\mathrm{a}}$ & $14.1(0.19)^{\mathrm{a}}$ & $2168(36)^{b}$ \\
\hline H. sexstylosa (hetero) & $81.4(1.4)^{\mathrm{b}}$ & $0.72(0.02)^{\mathrm{b}}$ & $16.6(0.27)^{\mathrm{a}}$ & $22.5(0.28)^{\mathrm{b}}$ & $12.3(0.18)^{\mathrm{b}}$ & $2466(36)^{\mathrm{a}}$ \\
\hline A. serrata & $79.6(1.0)^{\mathrm{b}}$ & $0.66(0.02)^{\mathrm{b}}$ & $18.1(0.32)^{\mathrm{b}}$ & $22.2(0.30)^{\mathrm{b}}$ & $13.3(0.19)^{\mathrm{a}}$ & $1994(29)^{b}$ \\
\hline A. fruticosa (hetero) & $100.0(1.4)^{\mathrm{a}}$ & $0.85(0.02)^{\mathrm{a}}$ & $21.7(0.41)^{\mathrm{a}}$ & $28.8(0.60)^{\mathrm{a}}$ & $12.0(0.17)^{\mathrm{a}}$ & $2312(39)^{\mathrm{a}}$ \\
\hline \multicolumn{7}{|l|}{ Canopy gap } \\
\hline H. lyallii & $186.4(2.3)^{\mathrm{a}}$ & $1.36(0.03)^{\mathrm{a}}$ & $22.5(0.32)^{\mathrm{a}}$ & $78.9(1.3)^{\mathrm{a}}$ & $14.1(0.18)^{\mathrm{a}}$ & $5189(91)^{b}$ \\
\hline H. sexstylosa (hetero) & $159.4(1.9)^{\mathrm{b}}$ & $1.02(0.02)^{\mathrm{b}}$ & $16.5(0.26)^{\mathrm{b}}$ & $72.1(1.1)^{\mathrm{a}}$ & $12.1(0.15)^{\mathrm{a}}$ & $6247(110)^{\mathrm{a}}$ \\
\hline A. serrata & $130.6(1.3)^{\mathrm{b}}$ & $1.07(0.02)^{\mathrm{b}}$ & $29.2(0.40)^{\mathrm{b}}$ & $52.6(0.6)^{\mathrm{b}}$ & $10.9(0.18)^{\mathrm{b}}$ & $5024(90)^{\mathrm{b}}$ \\
\hline A. fruticosa (hetero) & $230.6(1.3)^{\mathrm{a}}$ & $2.23(0.03)^{\mathrm{a}}$ & $37.2(0.52)^{\mathrm{a}}$ & $116.6(0.8)^{\mathrm{a}}$ & $13.2(0.15)^{\mathrm{a}}$ & $5214(58)^{\mathrm{a}}$ \\
\hline
\end{tabular}<smiles>C1CCCCC1</smiles>

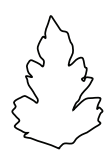

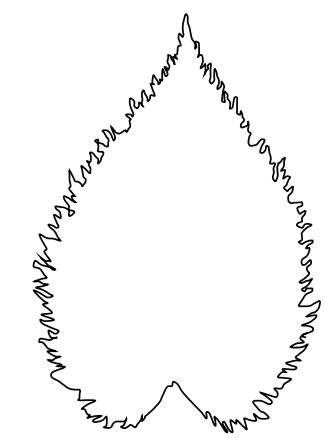

(a)

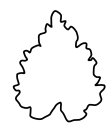<smiles>C1CCCCC1</smiles><smiles>C1CCCCC1</smiles>

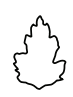

Hoheria lyallii

$$
\begin{aligned}
& \text { H. sexstylosa } \\
& \text { (hetero) }
\end{aligned}
$$

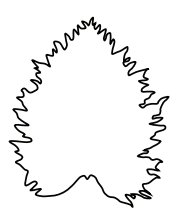

(b)
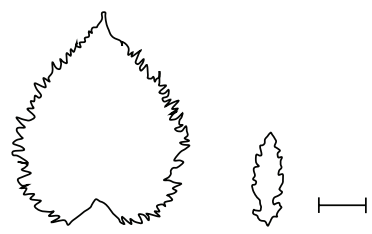

Aristotelia serrata

A. fruticosa (hetero)

(c)

FIGURE 1: Differences in leaf shapes of homoblastic and heteroblastic (hetero) species after 18 months growth in canopy gap (a), and forest understory (b) sties relative to their initial shape (partial shade $=\mathrm{C}$ ). $\mathrm{Bar}=2.5 \mathrm{~cm}$.
3.4. Seedling Survival and Growth. Heteroblastic species except $A$. fruticosa in the understory had $100 \%$ survival both in full-sun and forest understory sites. Only $86 \%$ of $A$. fruticosa seedlings survived in the understory. All homoblastic species had $100 \%$ survival only in the understory sites (Table 2). Growth in sun or shade environments did not consistently differ between the heteroblastic and homoblastic pairs (Figure 3). All the measured growth traits (height, number of branches, and total dry mass) were greater for heteroblastic $H$. sexstylosa than homoblastic $H$. lyallii in both gap and understory sites. Heteroblastic Aristotelia fruticosa was greater in growth traits than $A$. serrata in the understory but not in the canopy gaps (Figure 3). However, both heteroblastic species had greater proportional allocation to stems (main shoot and branches) than homoblastic congeners in gap and understory sites (data not shown).

3.5. Plasticity. There was a trend for greater plasticity in leaf morphological (serration, physiological $\left(A_{\max }\right)$, and anatomical traits (thickness of leaf blade, palisade mesophyll, and stomatal pore area) for heteroblastic species compared with homoblastic congeners. However, plasticity in growth (height increment) was only higher for heteroblastic $H$. sexstylosa than $H$. lyallii (Table 4).

\section{Discussion}

The two heteroblastic species examined exhibited consistent differences in leaf morphological traits in comparison to their congeneric homoblastic species. Heteroblastic species had consistently larger number of smaller leaves and higher branching frequencies, compared to their homoblastic congeners in both light environments. This may reflect some inherent features of the heteroblastic syndrome, and further species comparisons may provide evidence for this. Leaf serration in heteroblastic species changed dramatically across 


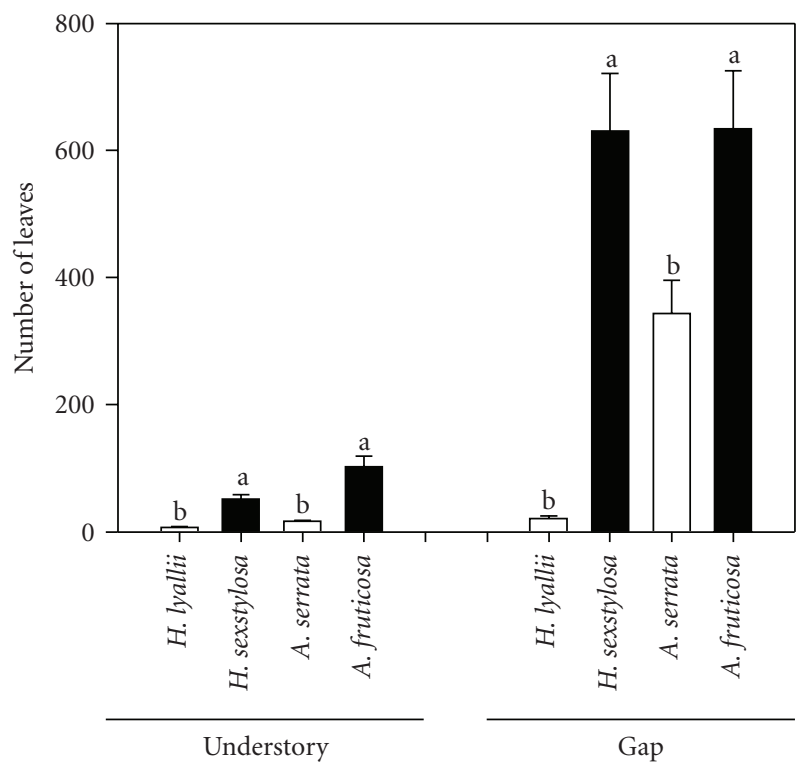

(a)

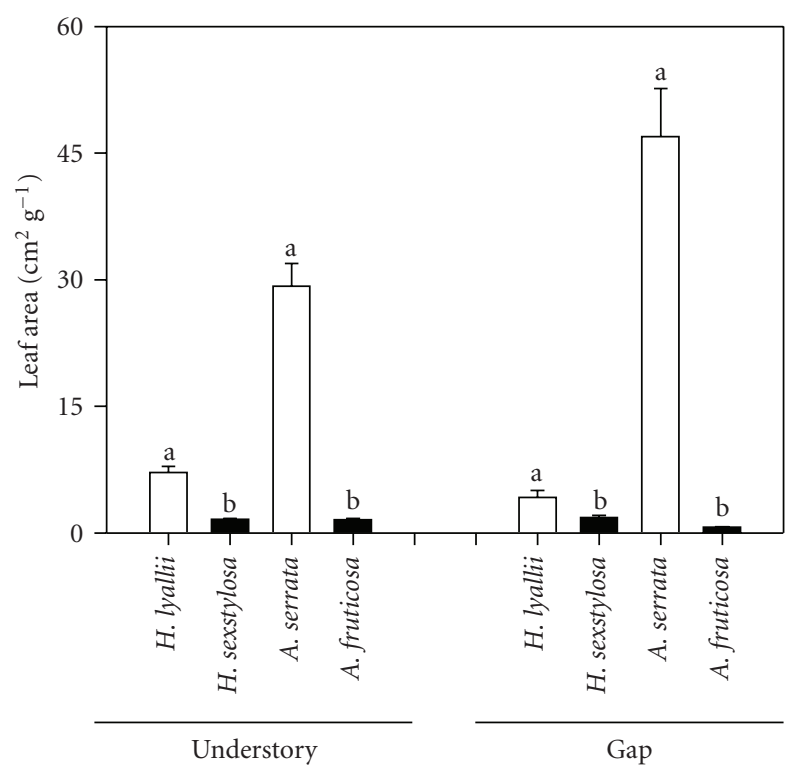

(b)

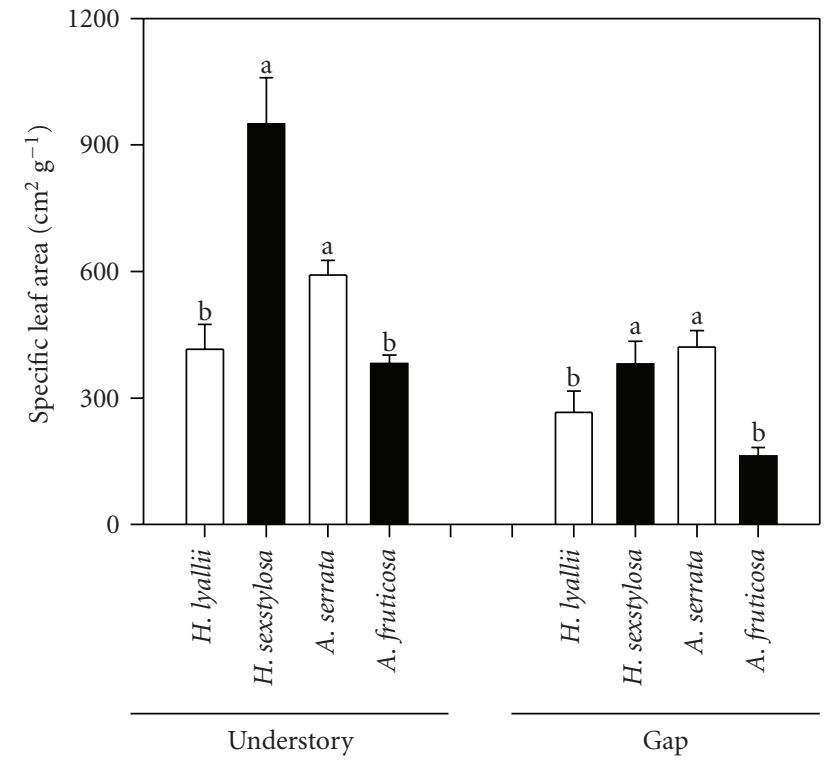

(c)

FIGURE 2: Differences in leaf morphological traits (leaf number/seedling (a), mean leaf size (b), and specific leaf area (c)) for homoblastic ( $\square$ ) and heteroblastic $(\square)$ Hoheria and Aristotelia species under canopy gap and forest understory light environments. Bars indicate \pm standard error of the mean. Means marked by different letter are significantly different at $P<.05$ level within a genus in gap or understory site.

light environments and had more serrated leaves in the gaps while serration was reduced in the understory in comparison to their initial leaf shapes (Figure 1, Table 2). Interestingly, homoblastic species reduced leaf serration in both gap and understory sites in respect to their initial leaf shapes. It appears that homoblastic species posses certain degree of plasticity in leaf serration but the response is more moderate and towards low light levels. The greater plasticity in leaf serration in gaps for heteroblastic species suggests that their seedling leaf morphology is an adaptation to high light environment.
The presence of serrated leaves in heteroblastic species in gaps is a xeromorphic feature that is often found in plants growing in high light [25]. However, differing results for leaf morphology have been reported in other heteroblastic species in response to light. For example, heteroblastic Ivy (Hedera helix) produced palmate juvenile leaves in deep shade, while the adult leaves were entire in high light environments [14]. In contrast, juveniles of tropical vines (Monstera spp.) that grow in the forest understory produced entire leaves while the adult leaves that are exposed to full sun had lobed leaves [6]. In Acacia, low light levels, delayed 


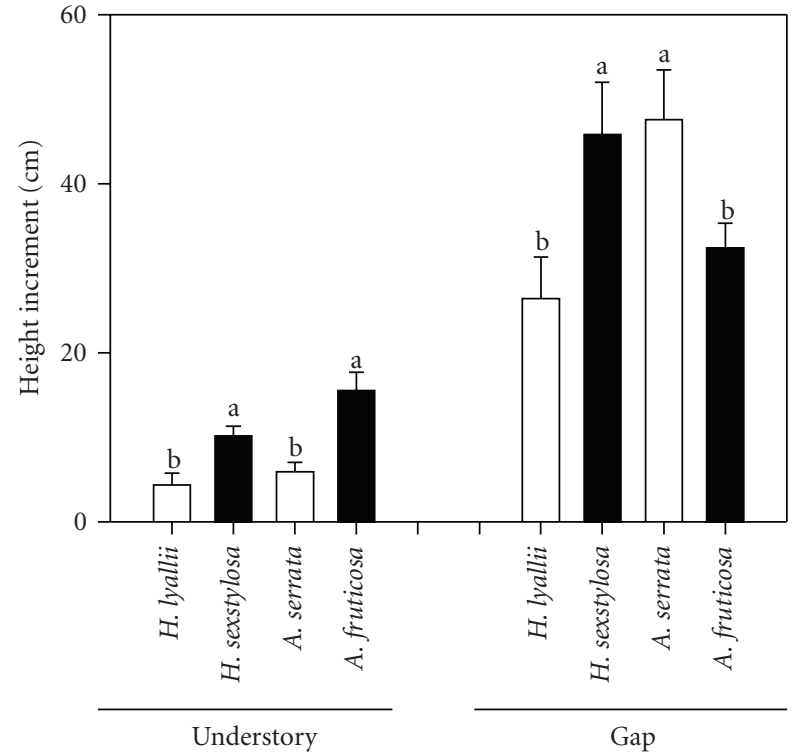

(a)

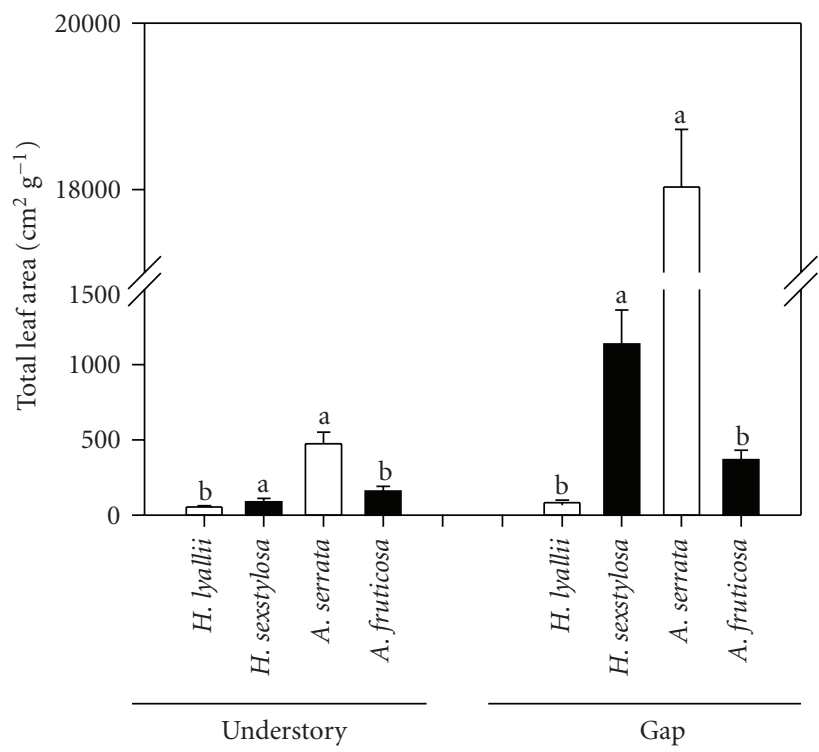

(c)

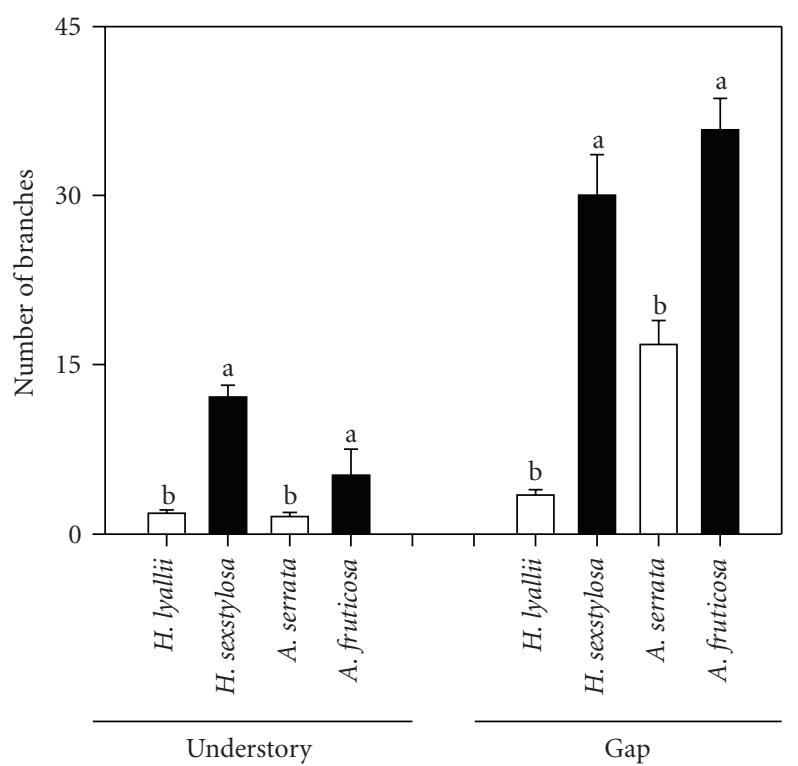

(b)

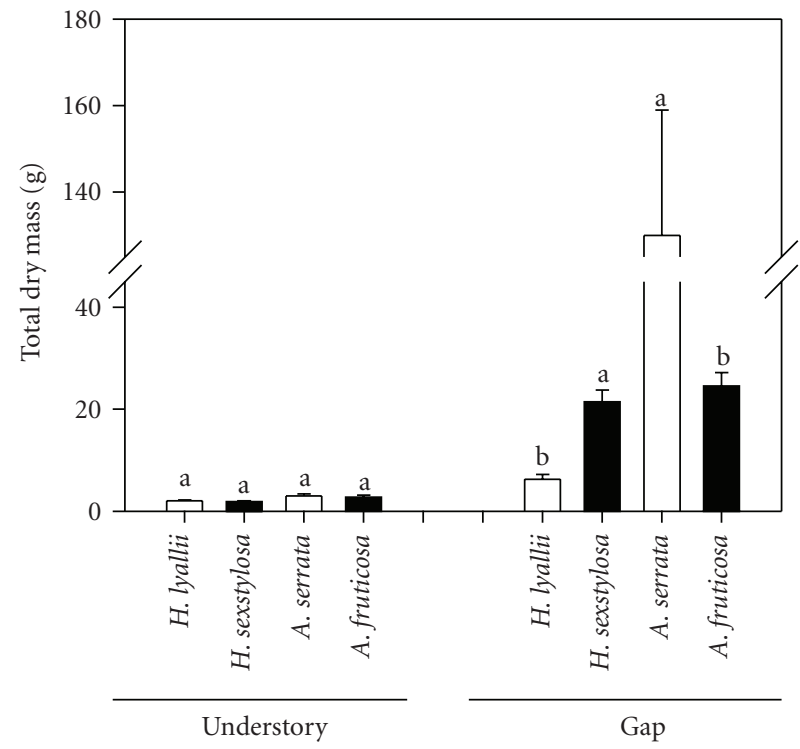

(d)

Figure 3: Changes in plant height (a), number of branches (b), Total leaf area (c), and total dry mass (d) for homoblastic ( $\square$ ) and heteroblastic (ם) Hoheria and Aristotelia species in canopy gap and forest understory sites. Bars indicate \pm standard error of the mean. Means marked by different letter are significantly different at $P<.05$ level within a genus in gap or understory site.

the formation of heteroblastic leaf morphology [17]. It does seem that the changes in leaf morphology of heteroblastic plants to light environment are species specific and cannot be generalized. It could also be possible that other exogenous factors (e.g., Gibberellins) that change their composition or quantity due to light or due to ontogeny might affect the leaf shapes of heteroblastic plants.

The studied heteroblastic species had greater branching, photosynthetic rate per unit leaf area, stomatal conductance than homoblastic congeners and 100\% survival in canopy gaps (Table 2). This better acclimation of heteroblastic species to changes in light environment is likely to be associated with their changes in leaf morphology since the changes in foliar traits affect the plant physiology such as photosynthetic rate, transpiration, and water use efficiency [26]. For example, the heteroblastic species by having smaller, serrated leaves posses thinner boundary layers allowing them to maintain leaf temperatures close to ambient (see $[25,27])$. In addition, the greater stomatal conductance and the presence of higher stomatal pore area (stomatal density $\times$ stomatal aperture length, Table 3 ) also increase the gas exchange for photosynthesis and regulate the leaf temperature by transpirational cooling [28]. As a trade off, higher stomatal conductance is also associated with more 
TABLE 4: Summary of plasticity values (maximum-minimum)/maximum for foliar responses calculated from mean values for homoblastic and heteroblastic (hetero) species between gap and forest understory light environments. ${ }^{*}$ Greater plasticity in heteroblastic species.

\begin{tabular}{|c|c|c|c|c|}
\hline & H. lyallii & $\begin{array}{l}\text { H. sexstylosa } \\
\text { (hetero) }\end{array}$ & A. serrata & $\begin{array}{l}\text { A. fruticosa } \\
\text { (hetero) }\end{array}$ \\
\hline \multicolumn{5}{|l|}{ Leaf morphology } \\
\hline Leaf lobing & 0.38 & $0.51^{*}$ & 0.19 & $0.24^{*}$ \\
\hline Leaf size & 0.58 & $1.17^{*}$ & 1.61 & 0.39 \\
\hline Total leaf area & 1.54 & $13.06^{*}$ & $37.96^{*}$ & 2.32 \\
\hline \multicolumn{5}{|l|}{ Leaf physiology } \\
\hline $\begin{array}{l}\text { Maximum photosynthetic rate } \\
\text { (unit leaf area) }\end{array}$ & 3.73 & $4.45^{*}$ & 4.1 & $6.42^{*}$ \\
\hline \multicolumn{5}{|l|}{ Leaf anatomy } \\
\hline Leaf blade thickness & 1.87 & $1.96^{*}$ & 1.64 & $2.31^{*}$ \\
\hline Palisade mesophyll thickness & 2.94 & $3.20^{*}$ & 2.37 & $4.05^{*}$ \\
\hline Stomatal aperture area & 2.39 & $2.53^{*}$ & 0.25 & $2.26^{*}$ \\
\hline \multicolumn{5}{|l|}{ Seedling Growth } \\
\hline Height increment & 2.53 & $10.70^{*}$ & 7.84 & 2.08 \\
\hline
\end{tabular}

water loss in plants [29]. However, heteroblastic species have less total leaf area at whole plant level relative to congeneric homoblastic species and, thus, likely to be more efficient in water use.

It appears that greater plasticity in leaf morphology of heteroblastic species between seedling and adult stage is also apparent at seedling stage and,thus, performed better in high light environment. Similarly, a study that examined the leaf structure of heteroblastic Eucalyptus globulus also found more sun-adapted traits in juvenile leaves with comparison to their adult leaves [13]. In contrast, Gould [7] found that field-collected heteroblastic Pseudopanax crassifolius juveniles exhibited a very similar leaf anatomy to adults, but seedling (height $<0.1 \mathrm{~m}$ ) leaf anatomy was more similar to shade-acclimated plants. I did not measure leaves at a consistent ontogenetic stage (seedlings at same size), and so the changes in leaf anatomy are likely to be confounded by ontogenetic and growth differences. Because the plants in canopy gap sites obviously had higher growth and, thus, some of these differences could be attributed to ontogeny. Therefore, I cannot assess whether the observed changes in leaf anatomy were due to environment or simply to developmental age.

The smaller serrated leaves apparently associated with the heteroblastic syndrome are likely to represent an adaptation to conserve water in high light environments. This could have contributed to $100 \%$ survival of heteroblastic species in canopy gaps though Darrow et al. [30] did not find any consistent trends in water use between homoblastic and heteroblastic species. It is unknown if this would change in more water-stressed conditions. In contrast, larger leaved homoblastic $A$. serrata had the lowest survival rate (Table 2), but the highest growth rate was (Figure 3(a)) in the gaps. While this is contradictory to my hypothesis, findings indicate that the growth rather than survival is more important for fitness benefit. However, the production of more branches with smaller leaves is likely to make heteroblastic seedlings less vulnerable to other environmental stresses (such as wind and snow) when growing in more open sites $[31,32]$. In the forest understory sites all homoblastic species survived but not heteroblastic species (Table 1). The greater vertical growth of heteroblastic species than homoblastic congeners (Figure 2) could probably be associated with the shade avoidance rather than tolerance for heteroblastic species, this is because the "shade-avoiding" strategy involves maximizing light interception through architectural traits that contribute to strong vertical growth $[33,34]$, the faster stem growth represents a carbon loss under light-limited environments and, therefore, sometimes causes death of seedlings in the understory [35]. This is likely to be associated with the lower survival of heteroblastic $A$. fruticosa in the understory.

Heteroblasty involves greater phenotypic plasticity than homoblasty and, in consistence with this, there was a trend for greater plasticity (sun/shade) for the studied heteroblastic species in the measured leaf physiological and anatomical traits of leaf blade thickness, palisade mesophyll thickness, and stomatal pore area (Table 4). The greater plasticity in leaf phenotype (leaf margins), leaf physiology, and anatomy probably was related with the better survival (100\%) of heteroblastic species in canopy gaps. However, irrespective of the dramatic differences in leaf margins of heteroblastic species in the understory, they do not have an advantage in low light relative to homoblastic congeners.

In conclusion, for these two species, the seedling leaf morphology is unlikely to represent adaptation for shaded conditions. Further studies are needed using more pairs of species across a range of light environments for better understanding of the significance of foliar traits on growth and survival of heteroblastic plants. Since seedlings growing in high light are also exposed to high temperature, dry soil conditions, and more exposure to wind, it would be interesting to examine the responses of heteroblastic species to these factors as well. 


\section{Acknowledgments}

The author acknowledges Victoria University of Wellington, New Zealand for awarding a Targeted Ph.D. scholarship and annual research grants to carry out this project. Wellington Botanical Society funded the field research expenses. The author also thanks Linley Jesson and Donald Drake for their helpful comments given on the paper.

\section{References}

[1] M. S. Greenwood, "Juvenility and maturation in conifers: current concepts," Tree Physiology, no. 15, pp. 433-438, 1995.

[2] R. A. Kerstetter and R. S. Poethig, "The specification of leaf identity during shoot development," Annual Review of Cell and Developmental Biology, vol. 14, pp. 373-398, 1998.

[3] C. S. Jones, "Does shade prolong juvenile development? A morphological analysis of leaf shape changes in Cucurbita argyrosperma subsp. sororia (Cucurbitaceae)," American Journal of Botany, vol. 82, no. 3, pp. 346-359, 1995.

[4] C. S. Jones, "The functional correlates of heteroblastic variation in leaves: changes in form and ecophysiology with whole plant ontogeny," Bulletin of the Botanical Society of Argentina, no. 36, pp. 171-184, 2001.

[5] H. Tsukaya, "Mechanism of leaf-shape determination," Annual Review of Plant Biology, vol. 57, pp. 477-496, 2006.

[6] D. W. Lee and J. H. Richards, "Heteroblastic development in vines," in The Biology of Vines, H. A. Mooney and F. H. Putz, Eds., pp. 205-243, Cambridge University Press, New York, NY, USA, 1991.

[7] K. S. Gould, "Leaf heteroblasty in Pseudopanax crassifolius: functional significance of leaf morphology and anatomy," Annals of Botany, vol. 71, no. 1, pp. 61-70, 1993.

[8] R. A. Sherry and E. M. Lord, "Developmental stability in leaves of Clarkia tembloriensis (onagraceae) as related to population outcrossing rates and heterozygosity," Evolution, vol. 50, no. 1, pp. 80-91, 1996.

[9] R. M. Greenwood and I. A. E. Atkinson, "Evolution of divaricating plants in New Zealand in relation to moa browsing ," Proceedings of New Zealand Ecological Society, no. 24, pp. 2133, 1977.

[10] N. D. Mitchell, "A study of the nutritive value of juvenile and adult leaves of Pseudopanax crassifolius," New Zealand Journal of Ecology, vol. 3, p. 159, 1980.

[11] L. Cockayne, "Observations concerning evolution, derived from ecological studies in New Zealand," Transactions of New Zealand Institute, no. 44, pp. 1-50, 1912.

[12] M. S. McGlone and C. J. Webb, "Selective forces influencing the evolution of divaricating shrubs," New Zealand Journal of Ecology, no. 4, pp. 20-28, 1981.

[13] S. A. James and D. T. Bell, "Influence of light availability on leaf structure and growth of two Eucalyptus globulus ssp. globulus provenances," Tree Physiology, vol. 20, no. 15, pp. 1007-1018, 2000.

[14] C. E. Rogler and W. P. Hackett, "Phase change in Hedera helix: induction of the mature to juvenile phase change by gibberellin $\mathrm{A}_{3}$," Physiologia Plantarum, no. 34, pp. 141-147, 1975.

[15] B. A. Horrell, P. E. Jameson, and P. Bannister, "Response of juvenile Pseudopanax crassifolius to gibberellic acid and paclobutrazol," New Zealand Journal of Botany, no. 27, pp. 591-594, 1989.
[16] A. A. Winn, "The functional significance and fitness consequences of heterophylly," International Journal of Plant Sciences, vol. 160, no. 6, pp. S113-S121, 1999.

[17] M. A. Forster and S. P. Bonser, "Heteroblastic development and the optimal partitioning of traits among contrasting environments in Acacia implexa," Annals of Botany, vol. 103, no. 1, pp. 95-105, 2009.

[18] Karori Wildlife Sanctuary Trust, Karori Wildlife Sanctuary Draft Management Plan, Karori Wildlife Sanctuary Trust, Wellington, New Zealand, 1997.

[19] NIWA, National Climate Centre database. Wellington, National Institute of Water and Atmospheric Research, 2005.

[20] J. Dawson and R. Lucas, Nature Guide to the New Zealand Forest, Random House, New Zealand, 2000.

[21] J. H. M. Thornley, "Instantaneous canopy photosynthesis: analytical expressions for sun and shade leaves based on exponential light decay down the canopy and an acclimated non-rectangular hyperbola for leaf photosynthesis," Annals of Botany, vol. 89, no. 4, pp. 451-458, 2002.

[22] S. E. Ruzin, Plant Microtechnique and Microscopy, Oxford University Press, Oxford, UK, 2000.

[23] P. M. S. Ashton, H. S. Yoon, R. Thadani, and G. P. Berlyn, "Seedling leaf structure of New England maples (Acer) in relation to light environment," Forest Science, vol. 45, no. 4, pp. 512-519, 1999.

[24] P. M. S. Ashton and G. P. Berlyn, "A comparison of leaf physiology and anatomy of Quercus (section ErythrobalanusFagaceae) species in different light environments," American Journal of Botany, vol. 81, no. 5, pp. 589-597, 1994.

[25] T. J. Givnish and G. J. Vermeij, "Sizes and shapes of liane leaves," The American Naturalist, no. 110, pp. 743-778, 1976.

[26] H. Tsukaya, "The leaf index: heteroblasty, natural variation, and the genetic control of polar processes of leaf expansion," Plant and Cell Physiology, vol. 43, no. 4, pp. 372-378, 2002.

[27] M. C. Lewis, "The physiological significance of variation in leaf structure," Science Progress, no. 60, pp. 25-51, 1972.

[28] G. D. Farquhar and T. D. Sharkey, "Stomatal conductance and photosynthesis," Annual Review of Plant Physiology, no. 33, pp. 317-345, 1982.

[29] F. I. Woodward, “Do plants really need stomata?” Journal of Experimental Botany, vol. 49, pp. 471-480, 1998.

[30] H. E. Darrow, P. Bannister, D. J. Burritt, and P. E. Jameson, "Are juvenile forms of New Zealand heteroblastic trees more resistant to water loss than their mature counterparts?" New Zealand Journal of Botany, vol. 40, no. 2, pp. 313-325, 2002.

[31] P. M. S. Ashton and N. D. N. D., "Performance of Shorea trapezifolia (Thwaites) Ashton seedlings growing in different light regimes," Journal of Tropical Forest Science, no. 4, pp. 356364, 1989.

[32] J. S. Day, "Light conditions and the evolution of heteroblasty (and the divaricate form) in New Zealand," New Zealand Journal of Ecology, vol. 22, no. 1, pp. 43-54, 1998.

[33] H. Smith, "Physiological and ecological function within the phytochrome family," Annual Review of Plant Physiology and Plant Molecular Biology, vol. 46, pp. 289-315, 1995.

[34] C. L. Ballaré, A. L. Scopel, and R. A. Sánchez, "Foraging for light: photosensory ecology and agricultural implications," Plant, Cell and Environment, vol. 20, no. 6, pp. 820-825, 1997.

[35] H. Smith, "Plant architecture and light signals," in Leaf Development and Canopy Growth, B. Marshall and J. A. Roberts, Eds., pp. 118-144, Academic Press, Edinburg, UK, 2000. 

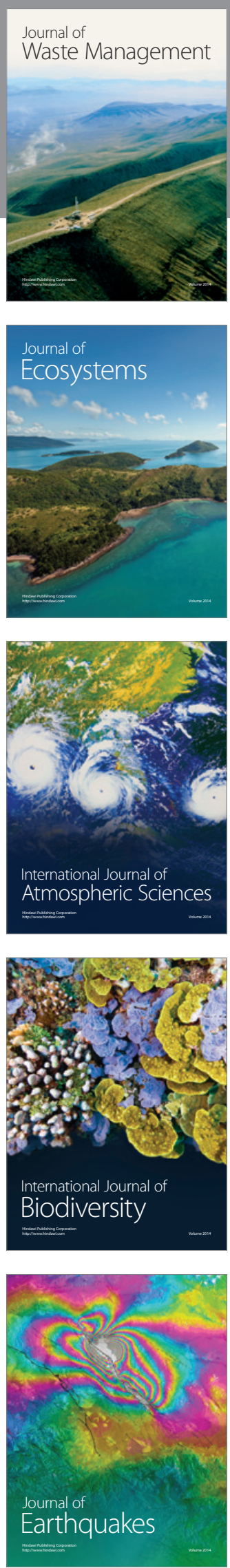
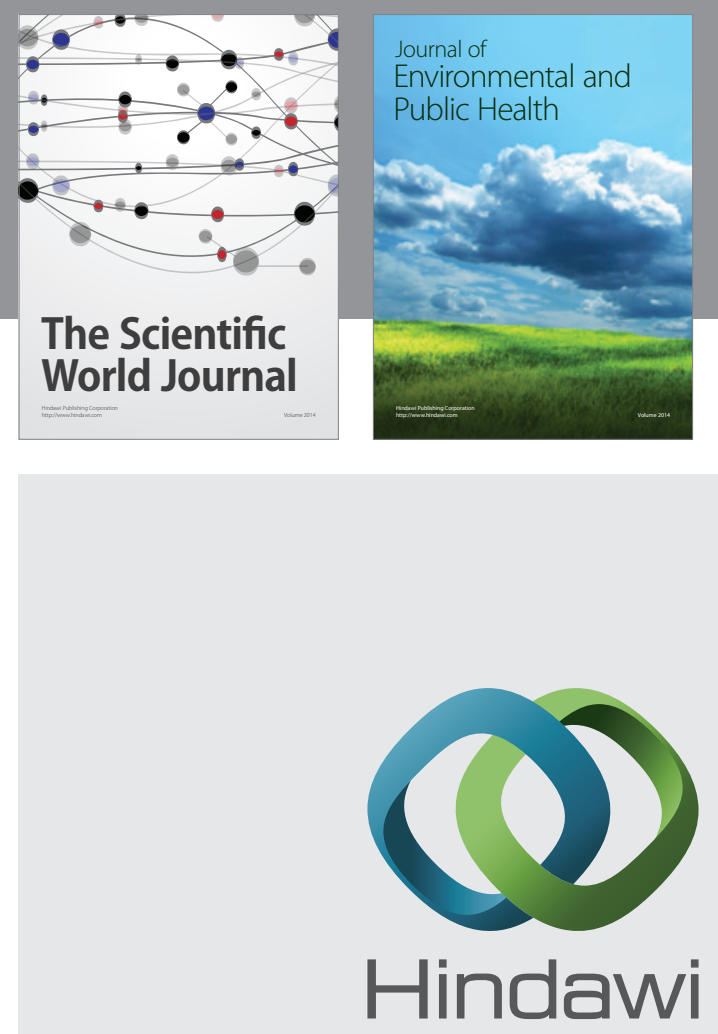

Submit your manuscripts at

http://www.hindawi.com
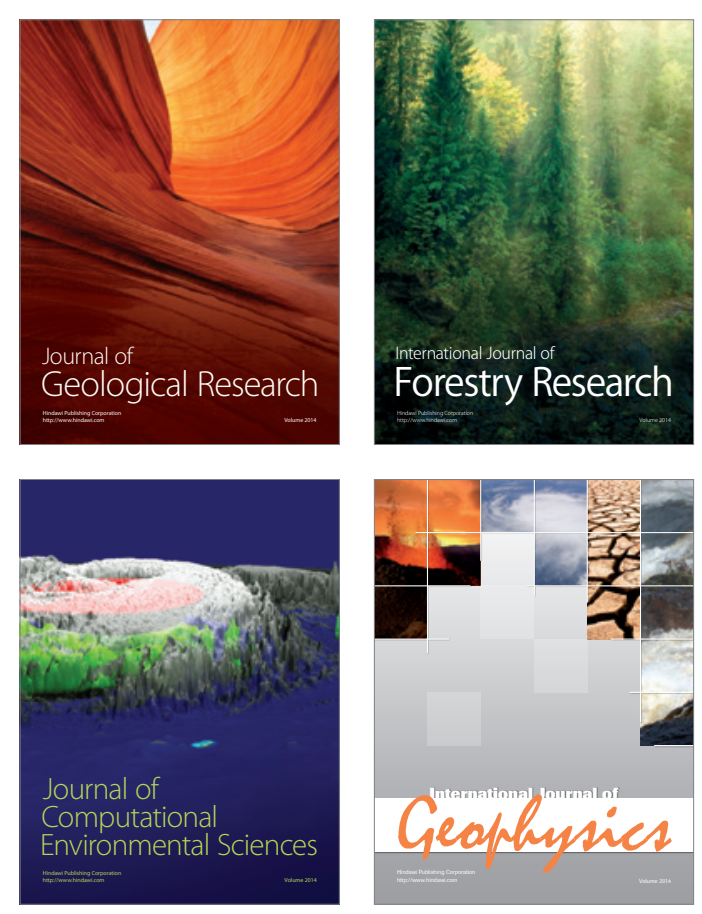
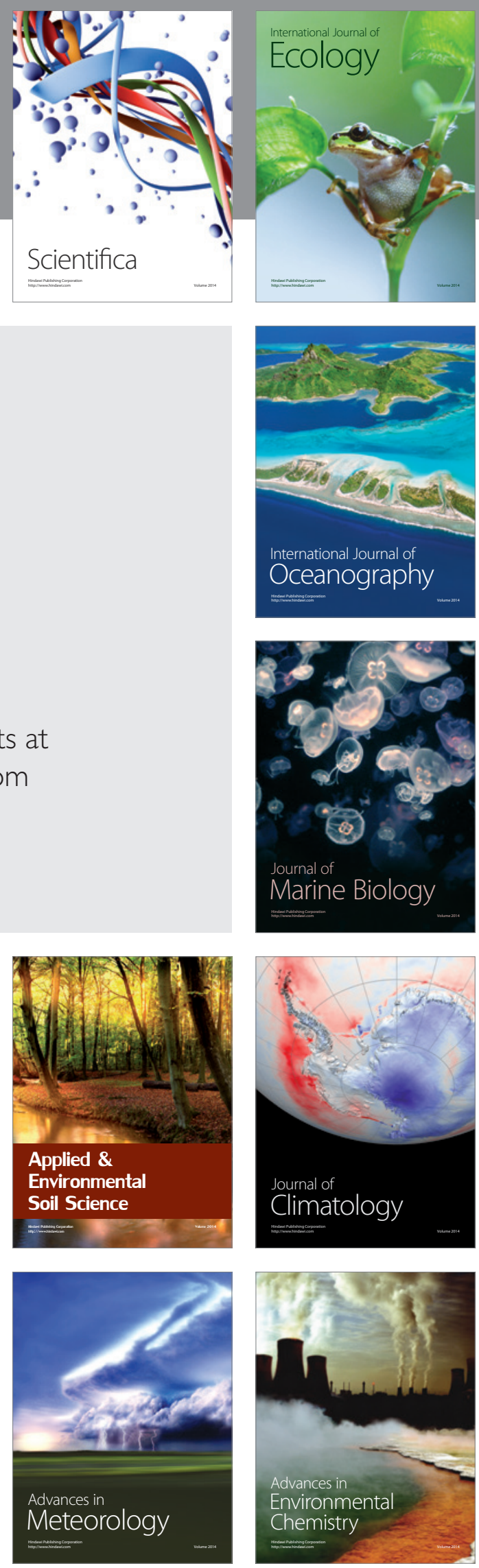